\title{
SPEECH ACTS USED IN THE FILM “ THE CURIOUS CASE OF BENJAMIN BUTTON”
}

\author{
HENDRI \\ Dosen Pada Program Studi Pendidikan Guru Sekolah Dasar Universitas Muhammadiyah \\ Palangkaraya
}

\begin{abstract}
This study intended to (1) identify the speech acts used, (2) find the most dominant speech acts used in the dialogue, (3) give brief description about the contexts of speech acts are realized, (4) explore the pedagogical implication of the study towards English learners.

The data of this research were conversation in film The Curious Case of Benjamin Button. The data were then analyzed based on the theory developed by Searle.There are several steps in analyzing the Speech acts in the film. The first step is transcribing the dialogues found in the film. Then identified the types of speech acts used. Next, classified them into the types of illocutionary acts. It refers to Searle's classification. After being classified the data were categorized based on the illocutionary force. Finally described the contexts of speech acts realized.

From the analysis, I found that the kinds of speech acts in dialogues of the film was dominated by directive speech acts, 340 times or $68 \%$. The second speech act performed was commisive, 64 times or $13 \%$. The third type of speech acts was expressive, 53 times or $11 \%$. The last type of speech acts was representative, 42 times or $8 \%$.. There was no declaration found in the dialogues of the film.

Directive is attempt by the speaker to get the addresse to do something, it influnced by the status between the speaker and the hearer. Commisive commits the speaker to some future course of act. Representative commits the speaker to the truth of the expressed proposition, it also deals with the use of language to tell people how things are. Expressive is used to express our feeling and attitudes. In declarative, the person performing the act must have authority to do it, and must do it in appropriate circumstance and with appropriate actions.

Students can learn from the film how people speak and how they perform an act by saying something and learn by using role-play. For learners, it is also an interesting thing watching film by observing the way people speak. At least it will give them inputs in terms of custom, behavior and also values hidden in the film.

Key words: Speech acts, illocutionary acts, illocutionary force.
\end{abstract}

\section{ABSTRAK}

Penelitian ini bertujuan untuk (1) mengidentifikasi penggunaan tindak tutur. (2) mencari tindak tutur yang dominan digunakan dalam dialog. (3) menjelaskan dalam konteks apa tindak tutur digunakan. (4) mengeksplorasi implikasinya kepada dunia pendidikan.

Data dalam penelitian ini adalah percakapan dalam film The Curious Case of Benjamin Button. Kemudian data tersebut dianalisis dengan menggunakan teori Searle. Ada beberapa langkah yang digunakan dalam menganalisa tindak tutur. Langkah pertama adalah mentranskribkan dialog dalam film, lalu mengidentifikasi tindak tutur yang digunakan. Kemudian mengklasifikasikannya menjadi beberapa tipe illocutionary act berdasarkan teori Searle. Setelah diklasifikasikan data tersebut dikategorikan berdasarkan illocutionary force. Akhirnya mendeskripsikan dalam konteks apa speech digunakan.

Berdasarkan hasil analisis ditemukan bahwa tindak tutur yang dominan digunakan adalah directive speech acts sebanyak 340 kali atau $68 \%$. Peringkat kedua adalah commisive sebanyak 64 kali atau sekitar $13 \%$. Ketiga adalah expressive sebanyak 53 kali dan yang terakhir adalah representative sebanyak 42 kali atau $8 \%$.

Siswa dapat mempelajari cara orang berbicara dan tindakan yang harus dilakukan melalui film. Bagi siswa, menonton sambil memepelajari bagaimana orang berbicara adalah suatu hal yang menyenangkan, paling tidak ada nilai kebudayaan dan kebiasaan yang bisa dipelajari dalam sebuah film.

Kata kunci : Tindak tutur, illocutionary act dan illocutionary force. 


\section{Background}

Language cannot be separated from society as the existence of language depends on the society itself. There will be no communication if no society shapes language. As Trudgil (1983) said that language and society are interrelated that it is impossible to understand one without the other. There is no human society that does not use language as the identity of the society. Trudgil (1983) points out that every social institution is maintained by language. To reveal our personal identity, our character and our background, we individually use language.

Language as a means of communication leads to the involvement of using speech acts. Everything that is said by at least two people in communication will deal with speech acts. All linguistic communications involve linguistic acts. The unit of linguistics is not, as has generally been supposed, the symbols, words or sentences, or even the token of the symbols of words and sentences but the production or issuance of the symbols or words or sentences in the performance of speech acts. More precisely, the production or issuance of a sentence token under certain conditions is speech acts and speech acts are the basic or minimal units of linguistic communication.

Speech acts in its varieties can also be in the form of dialogues that presents a discourse. The discourse of a film is visualized in pictures and also dialogues. It is used to present actor and setting and also plot in the film. The dialogues among actors and actresses are available, although a scriptwriter has manipulated the dialogues. The dialogues in the film could be found in the daily life, and the dialogues can be analyzed by using speech acts.

Film can be used as the media that can complete teaching materials. Through film, we will understand expressions which are used by characters in various contexts. Although the language used in the film is invented by the playwright, the language is used by native speakers in daily conversation. So it will be useful for the learners to learn English from the film.

Hopefully, by analyzing the Speech Acts, watchers or students especially would take some advantages by knowing the Speech Acts that appear in the dialogues of the film. The watchers or students most of whome prefer watching to reading would increase their understanding the utterances of the actors or actresses in English by recognizing the types of Speech Acts that they use in the dialogs of the film.

The "Curious Case of Benjamin" is an interesting film. It tells about a man who was born in his eighties and ages backwards, a man like any of us, who was unable to stop time. The story is set in New Orleans from the end of world war I in 1918 to the 21st century, following his journey that is as unusual as any man's life can be. The film was released in the United States on December 25, 2008, and received thirteen Academy Award nominations, including Best Picture, Best Director, Best Actor for Pitt, and Best Supporting Actress for Taraji P. Henson. It won three Oscars for Art Direction, Makeup, and Visual Effects.

\section{RESEARCH METHODS}

\section{Research Design}

This research applied descriptive qualitative method. Qualitative research is a 
research procedure which produces descriptive data in the form of written or oral words of people and behavior which can be observed. In this study I used a film transcript which covers spoken utterances. Whereas descriptive approach means a research method which uses technique of searching, collecting, classifying, analyzing the data and finally drawing conclusion from the analysis. I used the simple statistic computation to find the percentage of speech acts types used in the dialogue in order to simplify in drawing conclusion.

\section{Object of the Study}

The object of this study is film entitled "The Curious Case of Benjamin Button", directed by David Finch. This is an interesting film about a man who runs his life with unusual condition. The story is set in Baltimore; the baby is born speaking like an adult; has a long white beard; is born in a hospital, not at home; and is 70 years old, not 80 ; is not deserted by his father at a home for the elderly, but is cared for by Mr. Button and encouraged to go. He had to fight for his life with no where to go.

\section{Data Corpus}

This study is regarded to be qualitative since the data used are utterances spoken by the characters in the film "The Curious Case of Benjamin Button". In line with the topic of this study, that is the variety of speech acts used by the characters. The data corpus covers speech acts found in the film "The Curious Case of Benjamin Button". The characters are Benjamin, Daisy, Caroline, Dorothy Baker, Monsieur Gateau, Blanche Devereux, Martin Gateau, Man at Train Station, Teddy Roosevelt, Thomas Button, Priest
Giving Last Rite, Doctor at Benjamin's Birth, Caroline Button, Queenie, Tizzy.

\section{Procedures of Collecting Data}

The data was collected from a film. The next step was transcribing and then selecting the speech acts used by classifying the acts done by all of the characters in the film. The speech acts produced by all characters were then noted.

\section{Data Analysis}

Using qualitative analysis based on the pragmatics theory the data were analyzed. The speech acts in this study used the theory developed by Searle (Searle, 1976 in Levinson, 1983 and Marmaridou, 2009). The steps are:

1. Transcribing the dialogues in the paper.

2. Identifying the types of Speech Act used

3. Classifying them into the types of illocutionary acts. It refers to Searle's classification.

4. After being classified the data were categorized based on the illocutionary force.

5. Describing the contexts in which speech acts realized.

6. Exploring the pedagogical implication of the study for English language learning.

\section{FINDINGS AND DISCUSSIONS}

\section{Description of the Data}

The data about speech acts within the film "The Curious Case of Benjamin Button" were identified and classified based on Searle's classification: representative, directive, commisive, expressive and declarative. The summary of the speech acts categories is shown in the following table. 
Table 1. Summary of speech Acts Classification

\begin{tabular}{|l|l|c|c|}
\hline No & Speech Acts & Frequency & Percentage \\
\hline 1 & Directive & 340 & $68 \%$ \\
\hline 2 & Commisive & 64 & $13 . \%$ \\
\hline 3 & Representative & 42 & $8 . \%$ \\
\hline 4 & Expressive & 53 & $11 . \%$ \\
\hline 5 & Declaration & - & - \\
\hline & Total & 499 & $100 \%$ \\
\hline
\end{tabular}

From table 1, we can see that speech acts done by characters is dominated by directive speech acts, it is 340 or $68 \%$. It is attempted by the speaker to get the addressee to do something, as requesting, questioning, suggesting, , ordering, and commanding.

The second type of speech acts performed is commisive. It happened 64 times or $13 \%$, which commit ourselves to doing things as in promising, undertaking, threatening, vowing, offering. It also commits the speaker to some future course of act.

The third type of speech acts is expressive. It happened 53 times or $11 \%$, it expresses a psychological state in the speaker regarding a state of affairs that expressive refers to or presupposes but does not assert. It used to express our feeling and attitudes as in apologizing, thanking, welcoming, congratulating, blaming, pardoning, praising, condoling.

The last type of speech acts found in the dialogue is representative. It happened 42 times or $8 \%$, which commit the speaker to the truth of the expressed proposition, it also deals with the use of language to tell people how things are as asserting, boasting, stating, claiming, complaining, , and reporting.

There was no declaration found in the dialogues of the film. which bring about change in the world through utterances, as in declaring war, christening, firing from employment, nominating a candidate, dismissing, naming, appointing, excommunicating, and sentencing. It will effect immediate changes in the institutional state of affairs and which tend to rely on elaborate extralinguistic institution.

\section{The Contexts of Speech Acts}

Context refers to the things going on the world outside the text. Within the context we can identify three different aspects: field, tenor, mode. Field refers to what is going on which includes activity focus (the nature of social activity), and object focus (the subject matter). Tenor refers to the social relationship between those taking part. This include status or power (agent roles, peer, or hierarchic relations), affect ( degree of like, dislike or neutrality, and contact (frequency, duration and intimacy of social contact). Mode refers to how language is being used whether the channel of communication is spoken or written.

Directive is attempt by the speaker to get the addressee to do something. This expreession happened when the speaker want the hearer to do something, it can be in goods and services. The realization of the utterance influnced by the status between the speaker and the hearer. When the speaker's status is higher than the hearer, he will used the polite one, but when the speaker and hearer have the same status they do not use the polite one. Status of the speaker and hearer influence the use of speech acts.

Commisive commits ourselves to do things as in promising, undertaking, threatening, vowing, offering. It also commits the speaker to some future course of act. This expression can be realized when has the authority on the utterance. For example, when Daisy's grand mother asked 
Daisy to get bact to her room and she threated her. Speaker can not do a threatening when he has not authority on the hearer. This effect the hearer to do what we need from him/her.

Representative commits the speaker to the truth of the expressed proposition, it also deals with the use of language to tell people how things are. The expresion of this utterance can be realized when hearer believed on the speaker. Speaker needs to make sure that the hearer believe on him/her. When the hearer believe on him so the expression can be accepted by the hearer.

Expressive expresses a psychological state in the speaker regarding a state of affairs, it is used to express our feeling and attitudes. This expression happeneed when hearer need some supports from the others. For example, when Benjamin's mother was pass away Daisy expressed her condolance to Benjamin to support him to be strong. She wanted him to know that she could feel want he felt, hopefully it would help him to feel better.

Declarative brings about a change in the world through utterances, as in declaring, christening, firing from employment, nominating a candidate, In the case of declarative speech acts, the person performing the act must have authority to do it, and must do it in appropriate circumstance and with appropriate actions. For instance, it is not enough for someone to break a bottle of champagne on the bows of a ship, and say I name this ship Venus, for the ship either to acquire an official name, or to change its name. A proper ceremony must be enacted, with official recognized participants. The same is true of christening a baby. Even in the case of resigning from a job or position, just saying I resign, at breakfast, say, does not constitute a resignation: there are proper ways of resigning and channels for communicating such a decision.

\section{Pedagogical Implication}

The result of the study will be useful for a consideration of language teaching. Understanding the language usage which is related to the communicative function is completely needed. In turn, the perspective teacher of English will be able to become model of the language use for their students. seeing the importance of speaking naturally like the way native speaker use the language raises the awareness of achieving pragmatics competence. This competence can be achieved by understanding the contexts of the language use, situational and sociological contexts.

In order to achieve the sociological competence language teacher need to consider the sociological factors, such as power relation and social distance in developing teaching material. Speech acts as the expression will be more appropriate if the teacher of English not only introduce the students to the various of the speech acts but also give the contexts when the forms are appropriate and to whom the forms are appropriately addressed.

The teacher need to explain the relationship between speaker and addressee whether they are intimate or distance. The factor influences the choice of speech acts. Teacher needs to give example of speech acts which are normally used within the family, with a close friend, and with a person who has power.

In speech acts students can learn from a film how people speak and how they perform an 
act by saying something and learn by using roleplay. For learners, it is also a very interesting thing watching film by observing the way people speak. At least it will give them inputs in terms of custom, behavior and also values hidden in the film.

The language of the film consists of vocabulary, grammar, syntax, and sounds. Vocabulary consists of words, which represent things or abstraction, while grammar and syntax are means by which the words are arranged. The sounds are meant the speech sounds spoken by the characters in films.

Learning English through film viewing represent a novel approach for some students preconceived notions of learning English is based on their past learning experiences. For the most part such experiences are text book-oriented and test-driven, with the focus on form rather than meaning and accuracy rather than communication. Such standard teaching materials lack of realistic and meaningful context and fail to deal with contemporary issues that are relevant to their lives.

Hopefully, this film will give some advantages for students, how a man who was born in unusual condition keep fighting for his life. He never think about his weakness, the only things in his mind is how to give the best he has, so that people will give a big attention and appreciation for what he has done. Never complain on what happened to you but the important thing is how to make something weird be priceless.

\section{CONLUSION AND SUGGESTION}

\section{Conclusion}

Based on the findings and discussion of the research, the conclusions are formulated as follows:

The speech acts found in the dialogue of "The Curious Case of Benjamin Button" film done by the characters are directive, commisive, representative, and expressive. There was no declaration found in the dialogues of the film.

The dominant speech acts done by the characters is directive, speech acts, it is 340 or $68 \%$. In this film the actors did questioning dominantly, it means that there were questions need to be answered. The questions that took the questioners to the curiousity. The curiousity about Benjamin and the people around him.

Directive is attempt by the speaker to get the addressee to do something. It influnced by the status between the speaker and the hearer. When the speaker's status is higher than the hearer, he will use the polite one, but when the speaker and hearer have the same status they do not use the polite one. Status of the speaker and hearer influence the use of speech acts. Commisive commits ourselves to do things, it also commits the speaker to some future course of act. This expression can be realized when the speaker has authority on the hearer. For example, when Daisy's grand mother asked Daisy to get bact to her room and she threated her. Speaker can not do a threatening when he has not authority on the hearer. This effect the hearer to do what we need from him/her.Representative commits the speaker to the truth of the expressed proposition, it also deals with the use of language to tell people how things are. The expresion of this 
utterance can be realized when hearer believed on the speaker. Speaker needs to make sure that the hearer believe on him/her. When the hearer believe on him so the expression can be accepted by the hearer. Expressive expresses a psychological state in the speaker regarding a state of affairs, it is used to express our feeling and attitudes. This expression happeneed when hearer need some supports from the others. For example, when Benjamin's mother was pass away Daisy expressed her condolance to Benjamin to support him to be strong. She wanted him to know that she could feel want he felt, hopefully it would help him to feel better. Declarative brings about a change in the world through utterances, In the case of declarative speech acts, the person performing the act must have authority to do it, and must do it in appropriate circumstance and with appropriate actions. For instance, it is not enough for someone to break a bottle of champagne on the bows of a ship, and say I name this ship Venus, for the ship either to acquire an official name, or to change its name. A proper ceremony must be enacted, with official recognized participants. The same is true of christening a baby. Even in the case of resigning from a job or position, just saying I resign, at breakfast, say, does not constitute a resignation: there are proper ways of resigning and channels for communicating such a decision.

In speech acts students can learn from a film how people speak and how they perform an act by saying something. From a film we can see and hear the English from the native, it will help learners to find the right way in pronouncing the words and to find the contexts of the utterances are realized. it is also an interesting thing watching film by observing the way people speak at least it will give them inputs in terms of custom, behavior and also values hidden in the film.

\section{Suggestion}

It is suggested that when people watching film, they do not only see the story or the actor and the actress, but also learning and understanding the language used in a film specially the speech acts used. In the film we can learn about the pronunciation and also the culture involve in the film.

English teachers should not only use English text books for teaching, but they also should take other source as the facility in learning process. Watching western film can be an alternative source because it shows cultural and language expression

\section{BIBLIOGRAPHY}

Austin, J.L. (1982). How To Do Things With Words. Cambridge: Harvard University

Bogdan, R.C. S.K. Biklen. 1998. Qualitative Reasearch in Education. London Allyn and Bacon.

Butt, David et.al. 2001. Using Functional Grammar: an Explore's guide (second edition). Sydney: Macquire University.

Clark. H. 2002 Responding to indirect speech act. http://psychology.stanford.edu/ herb/1 970s/Clark.responding.79.pd. (17 June 2009)

Cohen. R.P. and Perault. R. C 2009. Elements of a Plan-Based Theory of Speech Acts. http://pdf serve.informaworld.com.(17 July 2009).

Hurford, James R. And Heasley, Brendan. 1983. Semantics: A Course Book. New York: Cambridge University.

Thomas, J. 1996. Meaning and Interaction: An Introduction to Pragmatics. London and New York.

Kreidler, W.C. 1998. Introducing English Semantics. London. 
Leech, G. 1983. The Principle of Pragmatics. New York: Longman Inc.

Levinson, C.S. 1983. Pragmatics. Cambridge: Cambridge University Press.

Lyon's, J. 1991. Semantic. London: Cambridge University Press.

Marmaridou, S.A. 2000. Pragmatic meaning and Cognition. Philedapia: John Benjamin Publishing. Co.

Richardson, Robert. 1996. Literature and Film. Canada: Indian University Press.

Searle, J.R. 1985. What Is Speech Acts? London: Cambridge University Press.

Thomas, J. 1995. Meaning Interaction: an Intro to Pragmatics. London: Pearson Education. 